\title{
The Role of School Administration in Implementation of ICT in Human Resources Administration in Public Secondary Schools
}

Katitia Melita David", Edward Tanui, Florence Oruta

Maasai Mara University, Kenya

\begin{tabular}{lr}
\hline DOI: $10.36348 / J A E P .2019 . v 03 i 10.004$ & $\mid$ Received: $12.10 .2019 \mid$ Accepted: $20.10 .2019 \mid$ Published: 26.10 .2019 \\
*Corresponding author: Katitia Melita David & Email: katitiamelita@gmail.com
\end{tabular}

Abstract

The purpose of this study was to find out how school administrators implement ICT in human resource administration in public secondary schools in Kajiado County, Kenya. Descriptive survey design was therefore suitable for this study. The design was useful in describing the characteristics of a large population and made used large samples in making the results statistically significant. The target population for this study was the 61 public secondary schools' principals, 1220 teachers, 610 students, 25 ICT teachers, 6 Sub-county Directors of Education in the 6 Sub-counties and 1 County Director of Education in Kajiado County. The study used $30 \%$ of the accessible population as sample size. The sample size for this study was therefore 18 principals, 366 teachers, 8 ICT teachers, 183 students, 2 Sub- county Directors of Education and 1 County Director of Education. This study used questionnaires, Observation schedules and interview schedule as tools for data collection. The overall implication of the findings in this study was that use and implementation of ICT in all the departments of school administration of the public schools in Kajiado County was very low. The study concluded that most of the public secondary schools in Kajiado County had not embraced ICT in various areas of administration. Based on the findings, the study recommends that proper technology should be put in place by purchasing of the required ICT facilities in schools to enhance management of schools using the current technology.

Keywords: implement ICT, Kajiado County, public schools, management, school administrators, human resource.

Copyright @ 2019: This is an open-access article distributed under the terms of the Creative Commons Attribution license which permits unrestricted use, distribution, and reproduction in any medium for non-commercial use (NonCommercial, or CC-BY-NC) provided the original author and sources are credited.

\section{INTRODUCTION}

There is a growing demand on the need for school principals to effectively to integrate ICT in all their administration and management endeavors as well the existing environment to enhance professional output [1]. School principals; therefore have no option but to embrace the use and integration of ICT in their schools. According to Okumbe [2], the principal is charged with the task of managing curriculum and instruction, staff personnel, student personnel, school plant, finances and school community relations. Thus, the principals are charged with the responsibility of carefully planning and utilizing the available resources in the school to achieve the institutional goals.

School administration has an essential role in ascertaining that education is put across to students as recommended [3]. The school administration is also tasked with the responsibility of overseeing student enrolment in the school, finance availability to sustain the daily school activities, educational resources availability to the school, as well as human labor to facilitate school administration [4]. Additionally, the school administration has to monitor and record all the school activity details manually in the school books and records [5]. However, it has been noted that technology has great prospects to provide new kinds of school administrative opportunities [6]. In a survey carried out in Sweden, it was established that ICT provide a positive impact on school administration when it is integrated in the management of schools [7]. In Kajiado County, the Public secondary schools can also leverage on the positive impact of ICT implementation to enhance school administration, which will boost effectiveness.

According to Zainally [8] ICT integration provides facilities and possibilities for the education administrators to perform their tasks. In this regard, ICT integration can be realized in student management for example students' records and management of other resources in an education system. Wiley [9] notes that school principals need effective and fast communication and accessibility to information. This is because school managers need to correspond through email and the internet, create websites for school 
marketing so as to communicate to parents, other school administrators, business executives, school suppliers and the wider community. Public schools in Kajiado County still use manual and traditional ways in schools management; hence, they need to adopt ICT in effective communication both internally and externally.

Uwadia [10] emphasizes that ICT serves as a tool for increased productivity and effective decisionmaking. For instance, the knowledge of ICT can be explored by the secondary school managers to ensure effective delivery of services, enhanced communication, proper maintenance of students' record system and maintaining academic planning among others. He further observes that in the school system today, it seems impossible to ignore the place of ICT hence school managers are faced with the challenge of incorporating ICT into the management of schools in meaningful and productive ways. Information communication technology can improve or enhance management duties of a school principal [11]. For instance, computer as one of the ICT facilities can provide better management results. It is also the duty of the school management to monitor the enrollment of students in the school, availability of educational resources, human labor and availability of finance to sustain the daily activities of the school. Alexis (2003) argues that school management has to monitor all these records of the school activities by entering the details manually on the books and records of the schools. Therefore, with the introduction of ICT in public schools in Kajiado County various programmes can be used to monitor daily activities in the school by click of a button.

According to the Kajiado County Education Office [12], out of the 61 public secondary schools in the County, only 15 of them, (12\%) implemented ICT in school administration Kajiado County Education Office, 2016. According to the report, Integrated Financial Management Information System (IFMIS) is never used, emails are rarely used and ICT technology is ignored in performance of most of the administrative tasks [13]. Failure to take full advantage of the opportunities offered by technological advances to education represents a drastic lag in skilled innovative manpower [14].

According to Alex [15], the incorporation of Information Communication Technology (ICT) in the administration of schools has positive effects. These may include improvement of the school standards in terms of academics, financial status and co-curricular activities [3]. This is not different from Laaria [16] who argues that it is the duty of the school administration to monitor the enrolment of students in the school, availability of educational resources, human labour and availability of finance to sustain the daily activities of the school. Public schools in Kajiado also have various departments that require ICT implementation to achieve high effectiveness.

The Government of Kenya has put in efforts to supply computers, construct computer laboratories, train teachers in some schools and mobilize support from development partners. The spirit behind the ESPICT programme was to enhance school management including monitoring attendances, performance, and staff training and recruiting of the staff [17]. To ease the many ills bedeviling the country's public secondary school administration including rising cases of student indiscipline highlighted by among other cases, increasing student strikes and indulgence in alcohol and drug abuse; budgeting, curriculum and co-curricular activities management [17]. The education of toady requires that both teacher and learners should implement ICT in the learning processes to enhance competitive of the learning process. This should also be the case in public secondary schools in Kajiado to make the school produce competitive knowledge and centres of excellence.

It is important to evaluate the implementation and use of ICT in secondary school's administration in the county for two main reasons. Firstly, there has been massive investment in buying ICT infrastructure. Information communication and Technology in education has been implemented in many countries around the world. Such plans reveal that educational innovations in ICT have been increasingly embedded within a broader framework of education reforms that aim to develop students' capacities for self-learning, problem solving, information seeking and analysis, and critical thinking, as well as the ability to communicate, collaborate and learn abilities that figured much less importantly in the curricula.

\section{LITERATURE REVIEW}

\section{ICT implementation in the Administration and Management of School}

According to the Organization for Economic

Cooperation and Development [18] Educational administrators and managers need to have basic information on student and teacher flows, probably also of school supplies, and how much the system is spending on various inputs, in order to make the most basic resource allocation decisions. Undoubtedly, ICT has played an important role in improving data collection in educational systems. It has also made these data more widely available to school personnel, parents, and the public at large through central school management web and in some countries through direct access to central or district databases by school personnel. These rudimentary data collection functions are expanded in some countries and regions by more sophisticated quality control data, namely student evaluation data. 
Maki [19] in a paper presented in Cyprus on ICT for administration and management of Cyprus secondary schools argues that the Cyprus Ministry of Education implemented a computer programme developed in Greece in order to manage information in secondary schools in relation to students and teacher's data. Schools in Cyprus use ICT for managerial purposes such as student management, (enrollment, absenteeism, grades, final exams), personnel management (absenteeism), human resource management and timetabling.

Carnoy [20] observes that ICT collects information from and distributes information to the different departments in schools and uses the information to extract greater effort from the different parts of the system. In many countries, such top-down use of ICT to monitor performance could be extended to collecting and disseminating information on student and teacher absenteeism, student attainment and other variables, all on a school-by-school basis [20]. Maki [19] observes that organizations and consequently schools depend on information systems to support the flow of data, information and knowledge about inputs, outputs, relationships among different environments.

Mugo [21] carried out a study to examine the factors that impact on data management using Management Information Systems by education administrators in public secondary schools in Thika West district, Kiambu County. The findings of the study indicate that $61 \%$ of the institutions never used computer software and $44 \%$ always used manual method to manage data, $29 \%$ indicate calculators were always used to manage data compared to only $6 \%$ indicate never. There is low use of computers in data management as only $20 \%$ of the respondents indicate that they used computers. This implies low levels of computer literacy and limited use of computers in data management. The findings also note that (75) percent of the officers at the District Education Office, (66.66\%) of the head teachers and $(52.7 \%)$ of Heads of Departments used computers compared to (50\%), $(22.2 \%)$ and $(13.8 \%)$ respectively using computer software.

\section{ICT use and Human Resource Management}

According to Vernon [22] ICT has been applied in all spheres: in health delivery, engineering, industry, business, and agriculture, military, security, law, politics and governance, all aspects of arts, science and education among others. Studies have shown that ICT has been applied in the administration of human resources. Abdul Razak \& Zohora [22] conducted a study to investigate the areas of ICT utilization among teachers and principals of Malaysian schools. Quantitative method was used in this study with a representative sample of 260 schoolteachers, teacherssupervisors and principals. The finding of the research demonstrates that $84 \%$ of the teachers were not aware of national ICT policy though it exists. Finding shows that most of the schools $(80 \%)$ do not have ICT policy at the school level though the facilities and equipment of ICT ware available in most Malaysian schools. Almost all the teachers have a high level of skills in using computer and profoundly all the teachers attain the basic skills needed for teachers in IT. Likewise, 95\% schools had photocopy machines and scanners while the multimedia projector is available in $85 \%$ schools. Besides, 72\% schools are equipped with a video camera, overhead projector and laptop. However, it was interesting that their expertise and skills were not integrated with educational management or with teaching/ classroom purposes. Rather they are used for daily administrative purposes. However, the study did not specify the type of schools that was carried out and it only used questionnaire for quantitative analysis. Moreover, the study was done in Malaysia, which is a developed country as compared to Kenya. Thus there is need to find out the application of ICT in public secondary schools in Kenya as the current study is done in one county only.

ICT have important roles to play in making school administration less burdensome and more effectively integrated to the official information flow about students, curricula teachers, budgets and activities through the educational system information pipelines. They are also a good means for informing community members (parents, politicians, and researchers) about educational news and policies. Some of the constraints in the management of schools include the problem of controlling large population of students as well as conducting examinations on a large scale. The fact that the schools are witnessing a tremendous growth in pupils' enrolment has made the management of schools' complex thereby, creating challenges ranging from the management of students and staff, community relations, supervision of instruction to the management of school finance. Supporting the observations is worth it because there is no time in the history of secondary school education in Kenya when principal have been faced with such multitudes of challenges.

It is the position of this study that administrative functions in schools are becoming increasingly complex in terms of enrolments, population mobility and social problems. This complexity requires the use of powerful administrative tools resulting in better communication, efficient operations and better personal services. One of such tools is ICT. The evolution of the ICT and its capability to handle diverse kinds of problems has made easy the mounting challenges created by the staggering development in secondary school education management.

The school principal needs information in ICT application for effective management of the school. This is necessary in the areas of budgeting, collection of 
student data, recording of results and effective keeping of school records. Data of various types could be programmed into the computer. Data on staff, teaching and learning could also be done though the effective use of ICT in schools. The introduction of ICT in the management of education could became an antidote in providing effective solutions to educational problems that would have been difficult, if not in possible to solve through human manual efforts. Commenting on the relevance of data in the educational system, it can be argued that effective recordkeeping is vital to educational development. In addition, he emphasizes that, it will be an impossible task to plan and administer any institution in which kept.

Consequently, the educational planners and administrators need to have adequate and accurate data of student enrolment, school personnel i.e. academic and non-academic staff and school records for effective planning and management of schools. One cannot overestimate the utilization of ICT in everyday activities of the school. Consequently, ICT assists the school administrator to meet the task of school management in the areas of curriculum and instruction, school community relationship and school business operations. In support of this, it is the view of this study that the introduction of ICT in schools enhances the daily school routine, programme, updating the evaluation of school programmes, solving individuals' or groups' as well as staff development.

There is no doubt therefore, that secondary school education has become more complex and hence its management demands more from the managers. The enormous rise in the number students in schools as well as the multiplicity of programmes have made school principals to handle large quantity of data which they must process speedily to provide information for the teaching service commission and ministry of education for effective management and decision making. Hence, the use of ICT in the management process is imperative for sustainable development. It has however been observed that in many public secondary schools' tools like computer, internets and other telecommunication technologies that can aid teaching and learning are hardly used or not available.

In A study conducted by Raby [23] on ICT integration in public secondary schools in Uganda. The sample of the study consisted of 12 secondary schools, 12 principals, three education officers, three curriculum developers and 20 students. Qualitative data was collected using interviews of principals, education officers and curriculum developers whereas questionnaires were administered to students. The results of the study reveal that in most public secondary schools, ICT application in human resource management is the responsibility of the school principal.
According to the study, ICT could aid instructional supervision through facilitating decision making process, planning, organizing, communicating, influencing, coordinating and evaluating. Further, the study observes that for a principal running a big school or institution, running various human resource areas like curriculum development, instructional supervision, staff and student, personnel administration, guidance and counseling, finance, community relations, construction and maintenance of facilities and special services could be tasking and time consuming. The study stresses that for the principal to function efficiently and effectively in the present computer age, he/she must rise to the challenge of adopting new technological resources and services in the management of the school. The study by Raby [23] however is carried out in Uganda unlike this study which is done in Kajiado County in Kenya hence it identifies a research gap in the implementation of ICT use in human resource management in Kajiado County.

According to Telem [24] ICT helps in streamlining management processes of the human resource especially in the area of communication. This is whereby, teachers used to refer to big logbooks to know which rooms were available for booking and who booked same and for how long, but with ICT, they could see the schedule for an entire month and know who booked them and on which date the rooms may be vacant. He further notes that ICT is a very important tool for information dissemination. This is because it helps communicate whatever information is available to the staff the moment they log in as they read, know, and act.

Abuga [25] conducted a study on the influence of principals' characteristics on integration of information communication technology in management of human resources in Nyamira County, Kenya. The study sought to establish the influence of principals' exposure to training in ICT, to establish the principals' level of education and to determine the influence the principals' age and the influence of gender on ICT integration. The study used descriptive survey with a target population of 90 secondary school principals, 600 teachers and 30 chairpersons of board of management of secondary schools in Nyamira County. Out of whom 30 were principals, 180 were teachers and 30 were members of board of management chairpersons were sampled using stratified proportionate sampling. The data collection tools were questionnaires for principals, teachers, and interview schedule for board of management. The data was analyzed according to themes and objectives. According to the research findings, majority of the teachers $(52 \%)$ do not use any form of ICT in their schools. In terms of human resource management, $77 \%$ of the principals do not have any formal training in human resource management. Other teachers indicate that they use some forms of ICT in their schools such as laptops, desktop 
computers, and cellular phones among others. The majority of the principals who were respondents reported that they do not use ICT to monitor human resource. Majority of teacher respondents $74.1 \%$ reported that they have not been through any form of ICT in-service training. Those who underwent any form of training only did it once in a year as $74.1 \%$ of the respondent's report. On the question whether teachers use ICT in recruitment and selection of human resource, majority $55.6 \%$ reveal that they do not use ICT in recruiting and selecting the human resource. The study suggests strategies to put in place for expansion of ICT in these schools, which include increase the number of computers as indicated by $63 \%$ of the respondents.

Training of teachers on ICT, having adequate forms of ICT and requesting the government to offer donation to public schools to facilitate ICT integration in management of human resource in public secondary schools. Further the researcher points out challenges of ICT integration in management of human resource in public secondary schools such as inadequate facilities and inadequate funds for installation as reported by 29.6 percent of the respondents, negative attitude towards ICT by the teachers, lack of trained personnel, high cost of installation and maintenance of computers and computer breakdown. Only $3.7 \%$ of the respondents said that there are no challenges facing ICT integration in the management of human resources in public secondary schools. On the measures that may be put in place to overcome the challenges faced in ICT integration, the respondents suggest on the use of computers more often, requested for donations to purchase ICT facilities and repair broken computers to enhance ICT integration in schools.

Training teachers on ICT would enhance the integration of ICT in public secondary schools on management of human resources [25]. However, Despite the research methodology used, this study is limited in data analysis techniques, data collection tools and in terms locale of the study. The study therefore creates a knowledge gap on the implementation of ICT use in personnel management in public secondary schools in Kajiado County. It is against this background that this study intends to examine the utilization of information and communication technology (ICT) in the effective management secondary schools in Kajiado County.

\section{METHODOLOGY}

This study adopted descriptive survey research design. This study was carried out in public secondary schools of Kajiado County. The target population for this study was the 61 public secondary schools' principals, 1220 teachers, 610 students, 25 ICT teachers, 6 Sub-county Directors of Education in the 6 Sub-counties and 1 County Director of Education in Kajiado County. The sample size for this study was achieved by taking $30 \%$ of the study population. Since the population for the schools was 61 public secondary schools in Kajiado, the sample of the sample was therefore 18 public secondary schools. The study adopted census survey in selecting the principals, subcounty and county directors. Puporsive sampling for students and simple stratified random sampling for teachers. The study used questionnaires, interviews, observation and document analysis. To establish the reliability of the research instruments, the researcher carried out a pre-test study in six secondary schools randomly sampled. Instrument reliability was determined through Cronbach Alpha coefficients. Qualitative data were organized into themes and patterns based on the study objectives and questions. Content analysis was used to analyze qualitative data from the interview guides. In content analysis, the researcher identified the recurring themes in the qualitative and also captured direct quotations of the key informants that provided explicitly response. Data was also analyzed using mixed model method, which included descriptive statistics. Descriptive statistics used included the frequencies, percentages, mean, standard deviation, cross-tabulation and t-tests.

\section{FINDINGS AND DATA ANAL YSIS The extent ICT been Implemented in Human Resource Management in}

\section{Secondary School Administration in Kajiado County}

The third research question of the study was to find out how school administrators implement ICT in human resources administration in public secondary schools in Kajiado County, Kenya. To achieve this objective, the study used descriptive statistics and cross-tabulations and the following sections present the results.

Table-13: ICT implementation in the Human Resources Administration

\begin{tabular}{|l|l|l|l|l|l|c|}
\hline & Never & Rarely & Undecided & Sometimes & Always & Mean \\
\hline Staff personal information records & $41.7 \%(141)$ & $42.3 \%(143)$ & $10.7 \%(36)$ & $2.7 \%(9)$ & $2.7 \%(9)$ & 2 \\
\hline Students admission details & $39.6 \%(134)$ & $45 \%(152)$ & $11.2 \%(38)$ & $2.4 \%(8)$ & $1.8 \%(6)$ & 2 \\
\hline Staff responsibility Records & $47.3 \%(160)$ & $39.9 \%(135)$ & $8.3 \%(28)$ & $2.1 \%(7)$ & $2.4 \%(8)$ & 2 \\
\hline Communication with school staff & $46.4 \%(157)$ & $40.2 \%(136)$ & $8.3 \%(28)$ & $3.3 \%(11)$ & $1.8 \%(6)$ & 2 \\
\hline
\end{tabular}

Source: Survey data, (2019)

The study sought to find the extent to which public secondary schools implemented ICt in the management of human resources. The respondent were asked to indicate the whether their school implemented 
ICT in staff personal information records, students admission details, staff responsibility records and communication with school staff. According to the study results, majority of the teacher, principals and ICT coordinators indicated that they rarely or never implemented ICT in their schools in staff personal information records, students' admission details, staff responsibility records and communication with school staff as shown in Table 13. The findings showed that majority of the public secondary schools in Kajiado had not implemented ICT in human resources administrations.

The study finding implied that majority of public schools still relied on traditional and manual ways of keeping staff information records, admission of students and all other matters in relations to human resources management. Filing and retrieving information in these traditional systems is very difficult especially for large schools that have many employees and students. Lack of ICT in management of human resources in public secondary school means that data on human resources can easily get lost hence school may fail to plan adequately because lack of accurate information. Employees and students can also use these weak structures to engage in unethical practices such being away without proper reasons among other things.

The finding of this study are supported by Abdul Razak \& Zohora [26] who argued that ICT have important roles to play in making school administration less burdensome and more effectively integrated to the official information flow about students, curricula teachers, budgets and activities through the educational system information pipelines.

Some of the constraints in the management of schools include the problem of controlling large population of students as well as conducting examinations on a large scale. Kuria [4] also highlighted that schools are witnessing a tremendous growth in pupils' enrolment has made the management of schools' complex thereby, creating challenges ranging from the management of students and staff, community relations, supervision of instruction to the management of school finance. Lack of implementation of ICT in Kajiado limits the schools from leveraging on ICT to achieve high level of efficiency in human resources management. Supporting the observations that there was no time in the history of secondary school education in Kenya when principal has been faced with such multitudes of challenges. Okello [26] also agreed with these views and reported that administrative functions in schools are becoming increasingly complex in terms of enrolments, population mobility and social problems.

Data on staff, teaching and learning could also be done though the effective use of ICT in schools. The introduction of ICT in the management of education could became an antidote in providing effective solutions to educational problems that would have been difficult, if not in possible to solve through human manual efforts. ICT assists the school administrator to meet the task of school management in the areas of curriculum and instruction, school community relationship and school business operations.

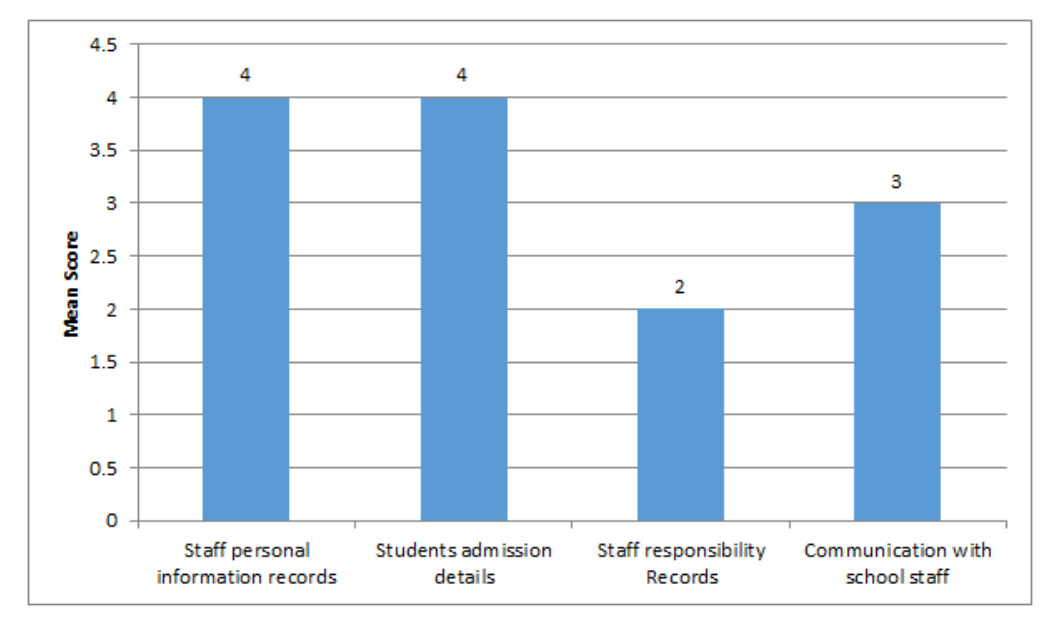

Fig-1: Areas where ICT has been adopted in Human Resources Management

Source: Survey data, (2009)

Figure 1 presents the areas of human resource management that public schools had moderately adopted the use of ICT. The leading areas in the human resources management that public secondary schools had adopted ICT was in staff personal information records, followed by student admission then communication with school staff. The findings implied based on the total number, the majority principals indicated their schools used ICT human resources management but the same information was not backed up by teachers as shown by 286 out of 316 who indicate there was low implementation of ICT in human resource management in their schools. The finding support a report by MOE [14] on the implementation 
Katitia Melita David et al; J Adv Educ Philos, Oct 2019; 3(10): 364-371

and use of ICT by secondary school teachers' indicated that only a low number of secondary school teachers were skilled in ICT. Over a half were reported to have trained on basic computer skills at certificate level, while others had developed ICT training through inservice courses. The findings established that technical trained individuals were more skilled in implementation of ICT than scholars were. Hence, high academic qualification negatively influenced the implementation of ICT in human resources management among the public secondary schools in Kenya. According to Dalgarno and Tinkler [27] teachers who have gone through ICT course are more effective in teaching by using technology tools as opposed to those that have no experience in such training.

\section{SUMMARY, CONCLUSIONS AND RECOMMENDATIONS \\ ICT Implementation in Human Resource Management}

The third objective of the study was to determine the extent of ICT implementation in human resources management of public secondary schools in Kajiado County, Kenya. In terms of human resource administration, ICT was moderately being applied in the areas of staff personal information, students' admission details, staff training and communication with the school. However, the implementation and use of ICTs is not that effective due to various challenges such as power shortage and inadequate facilitates hence rendering its application in the in the human resource administration to a small percentage.

\section{RECOMMENDATIONS}

The school administration should adopt the resource management practices, which will facilitate the process of monitoring the adequacy and status of the available ICT related resources in the school. Moreover, in this line, rules and regulations should be set to ensure adequate security is provided to the available facilities to prevent them from being stolen or destruction from viruses. Public Secondary schools should be encouraged to use ICT in management of finances.

\section{REFERENCES}

1. Muchiri, G. M. (2014). Factors influencing school principals in integration of ICT in administration of public secondary schools in Githunguri sub county, Kiambu County, Kenya. (Unpublished Master's Thesis); University of Nairobi.

2. Okumbe, S. (2011). Human Resources Management. An Educational Perspective. Nairobi: Educational Development and Research Bureau.

3. Sang, G., Valcke, M., Van Braak, J., \& Tondeur, J. (2010). Student teachers' thinking processes and ICT integration: Predictors of prospective teaching behaviors with educational technology. Computers \& Education, 54(1), 103-112.
4. Hennessy, S., Harrison, D., \& Wamakote, L. (2010). Teacher factors influencing classroom use of ICT in Sub-Saharan Africa. Itupale online journal of African studies, 2(1), 39-54.

5. Alexis, W. (2003). What Is Education? Retrieved on November 5, 2011. Retrieved from http://www.wisegeek.com/what-is-education.htm

6. Fleming-McCormick, T. (1995). District Response to the Demonstration: The Practice of Technology.

7. Swedish National Agency for School Improvement. (2015). Education Policy Outlook: Sweden. Retrieved from http://www.oecd.org/education/Education-PolicyOutlook-Country-Profile-Sweden.pdf

8. Zainally, H. (2008). Administration of faculties by information and communication technology and its obstacles. International Journal of Education and Information Technologies, 2(1)

9. Wiley, J. (2003). The school administrator's complete letter book with CD-ROM; [2nd ed]. New York: Jessey-Bass.

10. Uwadia, C. (2009). "Is ICT a sine-qua-non to modern University management?" Address delivered at the $46^{\text {th }}$ Edition of the Business Meeting of the Committee of Registrars of Nigerian Universities (CORNU), May $2^{\text {nd }}-4^{\text {th }}$.

11. Agabi, O. G., \& Uche, C. M. (2006). ICT adoption and information quality in effective university management. In $A$ paper presented at the 30 th Annual Conference of the Nigerian Association for Educational Administration and Planning. Enugu State: University of Science and Technology, Enugu. Oct (Vol. 3).

12. Balanskat, A. (2006). The ICT Impact Report, A review of studies of ICT impact on schools in Europe: European School net in the framework of the European Commission's ICT Cluster. Retrieved on July 2016. Retrieved from www.colccof.colfinder.

Org/sites/default/files/ict_impact_report_0.pdf.

13. Hove, M., \& Wynne, A. (2010). The experience of medium term expenditure framework \& integrated financial management information system reforms in sub-Saharan Africa: what is the balance sheet?.

14. Government of Kenya. (2010). ICT capacities and capabilities in secondary schools in Kenya 2009/2010, NCST No: 046, Nairobi, Kenya: Government Printer.

15. Alex, G. (2013). E-learning in secondary Schools in Kenya: A case of the Nepad e-schools International Journal of Information and Education Technology, 1 4, October 2011 no 4, 6.schools, Educational Research and Reviews 5, 6.

16. Laaria, M. (2013). Leadership challenges in the implementation of ICT in public secondary schools, Kenya, Journal of Education and Learning Vol. 2 No. 1:2013 32-43. Retrieved from http://dx.doi.org/10.5539/jel.v2n1p32

17. Richard, M. O. (2015). Factors Influencing The Implementation Of Information Communication 
Technology Projects In Public Secondary Schools In Kwale County, Kenya. Masters thesis: Published, University of Nairobi.

18. Organization for Economic Cooperation and Development. (2005). Annual Report for the $45^{\text {th }}$ Anniversary. Retrieved from https://www.oecd.org/about/34711139.pdf

19. Maki, C. (2008). Information and Communication Technology for administration and management for secondary schools in Cyprus. Journal of Online Learning and Teaching, 4 (3).

20. Carnoy, M. (2004). Information communication technology in education possibilities and challenges: Inaugural Lecture of the UOC 20042005 Academic Year 2004: Barcelona. Retrieved from

http//www.uoc.edu//inaugural04/dt/eng/carnoy004. pdf.

21. Mugo, P. M. (2014). Factors that Impact on Use of Education Management Information Systems: Case Study of Thika West District, Kiambu County, Kenya. Masters Thesis; Unpublished, Kenyatta University. Retrieved from ir.library.ku.ac.ke/handle/123456789/12272 on November 2016.
22. Vernon, R. (2001). Knowing where you are going: Information System for Agricultural Research management. The Hague: International Service for National Agricultural Research.

23. Raby, F. (2004). Barriers to adopting emerging Technologies in Education. Journal of Educational Computing Research, 22 (4), 455-472.

24. Telem, M. (2001). Teacher related factors influencing the integration of information technology in the teaching of mathematics in secondary schools in Kenya', 2, 14

25. Abuga, A.B. (2014). Influence of principals' characteristics on integration of Information Technology in management of human resource in Nyamira County, Kenya, Masters Thesis, University of Nairobi.

26. Abdul, R. \& Zohora, F. (2012). ICT Utilization among School Teachers and Principals in Malaysia: International Journal of Academic Research in Progressive Education and Development, 1(4) ISSN: 2226-6348

27. Winzenried, A., Dalgarno, B., \& Tinkler, J. (2010). The interactive whiteboard: A transitional technology supporting diverse teaching practices. Australasian Journal of Educational Technology, 26(4), 534-552. 